Steven Paget

Published in The Mariner's Mirror, 101:3, August 2015, pp.283-303. This is the post-print version and must not be copied or cited without permission.

\title{
On a New Bearing: The Re-organised Royal Australian Navy at War in Vietnam
}

The Royal Australian Navy (RAN) made a modest but important commitment of a single destroyer to the Vietnam War on a rotational basis between March 1967 and September 1971. The contrast between the deployments of the American-designed and built Charles F. Adams class guided missile destroyers and the British-designed Daring class destroyer, HMAS Vendetta, represented the fruition of a small navy being pulled in two different directions. The RAN was undergoing a transitional period, which saw the service increasingly align with the United States Navy. This was a monumental shift in policy, as the Royal Navy had provided a model for the RAN to emulate since its creation in 1911. The Vietnam War offered a clear test of standardization and demonstrated that common ship designs provided a platform for interoperability, but did not guarantee it. The Australian ships were able to make a worthwhile contribution to a predominantly American naval effort, but they faced a number of challenges in achieving interoperability. The basis for successful co-operation was provided by the existence of common procedures and standardized equipment, but was necessarily supplemented by ad hoc measures and impromptu workarounds.

The Australian Chief of Naval Staff, Vice Admiral Roy Dowling, wrote to the First Sea Lord, Lord Louis Mountbatten, in 1955:

The time has arrived when we must decide where we shall acquire ships and weapons - UK or USA. In the past we have depended entirely on UK...We have also deliberately and consistently worked on the principle of complete interchangeability with the $\mathrm{RN}$ in all respects, including officers, men, ships, equipment and logistics generally. We now find ourselves at the crossroads solely because we very much doubt whether UK can provide us with what we want in the future. We have no wish to become Americans but there is a very 
strong belief in this country that the sensible action for Australians is to acquire war equipment from the USA now. ${ }^{1}$

In 1911, when the Royal Australian Navy (RAN) was created, the Australian Minister for Defence, Senator George Pearce, described it as a 'navy within a navy'. ${ }^{2}$ By 1960 , in a brief preceding the visit of Vice Admiral Henry Burrell, RAN, to investigate potential naval acquisitions, Britain's Military Branch concluded:

The Australians are very independent people. They will welcome Admiralty advice and assistance but will not tolerate ready-made ideas being thrust upon them...Our own ideas must be worked in obliquely and presented as being designed for the benefit of the R.A.N. not merely as a prop or an adjunct of the R.N. in the Far East. ${ }^{3}$

Indeed, between the end of the Second World War and the onset of the Vietnam War, the RAN underwent significant changes, which reduced the influence of the Royal Navy (RN), but did not completely eradicate it.

A British Naval Station was established in Australia in 1859 and the influence of the RN reverberated throughout the RAN into the 1960s and to a degree, continues up to the present day. Robert Hyslop has asserted that:

The administrative tone and character of the [Australian] Naval Board was strongly British, simply tacked on to the Australian political fabric. To have a ready-made navy, Australia needed a ready-to-work naval administration and in 1911 it was not possible to allow time for this administration to evolve out of local conditions and experience. ${ }^{4}$

Although the administration and composition of the RAN was very much British in character, the Australians also gained practical experience of wartime operations working alongside the RN. During the first fifty years of its existence, the RAN reverted to RN control during the First World War, was initially placed on a war footing as a result of Britain's Imperial War Telegram during the Second World War and also served within a Commonwealth command

\footnotetext{
${ }^{1}$ Grey, Up Top, 21.

${ }^{2}$ Cooper, 'The Effect of World War II on RAN-RN Relations', 44.

${ }^{3}$ The National Archives of the UK (TNA), Head of Military Branch II, 'Future of the Royal Australian Navy: Brief for Discussion with Admiral Burrell', Undated, ADM 1/26681.

${ }^{4}$ Hyslop, Australian Naval Administration, 229.
} 
structure during the Korean War, Malayan Emergency and the Indonesian Confrontation. ${ }^{5}$ Eric Grove has opined that 'perhaps the RN and RAN have never been closer than they were in $1945^{\prime}$ and it is evident that the bonds remained intact throughout the beginnings of the Cold War. ${ }^{6}$ However, the period also witnessed the gradual decline of British influence in Asia, which prompted a shift in the RAN's alignment from the RN to the United States Navy (USN). The RAN's decision to purchase the American designed and built Charles F. Adams class destroyer as its new class of escorts in 1961 exemplified the RAN's increasing alignment with the USN.

\section{A Change in Outlook}

The pivotal influence of the Second World War in shaping the development of the RAN is unambiguous. During the war, the RAN operated with distinction in the Mediterranean, returned to Australia to protect convoys and the home island and contributed to USN operations in the Southwest Pacific. James Goldrick has asserted that the RAN's experiences during the Second World War ensured that the service 'left its childhood and entered adolescence'. ${ }^{7}$ The necessity of operating together cohesively and effectively offered the RAN an opportunity to obtain a close-up look at USN tactics, techniques and procedures (TTPs). The lack of standardisation between the RN and USN during the Second World War also prompted the RAN to adopt American tactical signalling procedures in the course of operations with their allies. Although they reverted back to British standards after the war, the

\footnotetext{
${ }^{5}$ In the shadow of war, RAN ships were placed under Admiralty control on 30 August 1939 but were to remain in Australian waters unless prior agreement was reached with the Australian government. The exception to the rule was the cruiser, HMAS Perth, which was operated alongside the RN in the West Indies.

${ }^{6}$ Grove, 'British and Australian Naval Policy in the Korean War Era', 246.

${ }^{7}$ Goldrick, ‘Australian Naval Policy’, 17.
} 
extensive experience obtained while operating with the Americans would resonate with many future senior officers of the RAN. ${ }^{8}$

Whilst the influence of the RN continued to permeate the RAN, the war necessitated that a thorough re-consideration of administration, equipment and outlook be conducted. Stephen Jurika, Jr., who became US Naval Attaché to Australia in 1947, recalled:

The Australians...could see the decline of Great Britain, its decreasing interest in east Asia, its loss of its Indian empire, the obvious politicization and upcoming independence of all of southeast Asia... So they were looking toward the United States and they made, during my tenure as naval attaché, a number of overtures toward the United States, deliberate overtures, seeking accommodation, which ultimately resulted in the ANZUS pact. ${ }^{9}$

The RAN made a clear decision to re-align its navy along the lines of the USN rather than be stymied by their traditional attachment to the $\mathrm{RN}$, which was conveyed to both the Americans and the British.

Following a meeting in 1955, Vice Admiral Sir Allan Scott-Moncrieff, Commander-inChief, Far East Station (RN), revealed that the Australian Minister for Defence Production, Sir Eric Harrison was:

perfectly candid and said that it appeared to them [the Australians] they should use the equipment of the people who would be fighting with them in war which, of course, would be the Americans as we would obviously pull out of Malaya as we had done the last time...In any case they know that in war the Americans will be their main protector and they will do everything they can to please the Americans and pin them down if possible. ${ }^{10}$

Two years later, during a visit by an Australian mission to the Pentagon, Sir Percy C. Spender, Australian Ambassador to the United States, proclaimed: 'The inevitable conclusion is that our destinies are intertwined - if war does break out, our forces will be engaged together. To wait until such a time would be foolhardy and tragic. ${ }^{11}$ Despite the fabric of the

\footnotetext{
${ }^{8}$ Cooper, 'The Effect of World War II on RAN-RN Relations', 50.

${ }^{9}$ United States Naval History and Heritage Command (NHHC), Reminiscences of Captain Stephen Jurika, Jr., U.S. Navy (Retired): Volume II, US Naval Institute, Annapolis, Undated, 744-745.

${ }^{10}$ Grey, Up Top, 20.

${ }^{11}$ National Archives at College Park (NARA), Maryland, 'Minutes of Australian Mission Meeting, 6th June 1957’, 20 June 1957, Record Group 59, Box 2.
} 
RAN being so deeply engrained with $\mathrm{RN}$ traditions, the Australians had made a clear decision to change course and focus on the likelihood of working closely with the USN, which in turn, was deemed to require a change in the composition of the fleet and the practices of the navy.

\section{The Influence of Allies}

As a smaller navy, which was geographically distant from her traditional allies, the RAN's desire to standardise with a larger partner was understandable. However, it was also essential that the larger navies wished to embrace the Australians. Given the longstanding link between the RAN and the RN, the British aspirations to see the Australians continue to develop their navy along similar lines was perhaps inevitable. That desire was also heightened by force reductions and mounting costs, which caused Britain's First Sea Lord to conclude in 1960 that the 'the R.N. was scaled down to the lowest level at which a reasonably balanced Navy could be maintained and even lacked some equipments which could only be supplied through co-operation with Allied Navies'. ${ }^{12}$ British hopes stretched well beyond mere compatibility and the Director of Plans even went as far as to propose an integrated Commonwealth (R.N./R.A.N./R.N.Z.N. [Royal New Zealand Navy]) Navy East of Suez'. The theory was that:

each Navy should make a specialised contribution towards a balanced naval force. This would enable each of them to make the best use of its resources by avoiding the wasteful overheads that are at present incurred by each trying to provide itself with a balanced force; and in the result a bigger effective force would be produced from the same total resources. ${ }^{13}$

\footnotetext{
12 TNA, 'Meeting Between First Sea Lord and Australian C.N.S.', 13 January 1960, ADM 1/26681.

13 TNA, Head of Military Branch II, 'Future of the Royal Australian Navy: Brief for Discussions with Vice Admiral Burrell', 8 January 1960, ADM 1/26681.
} 
Although it was recognised that a fully integrated Commonwealth fleet 'may be at best a distant aim, or at worst unattainable in full measure', it was believed that the 'pursuit of progressively closer co-operation between these Navies is a realistic - perhaps the only realistic - policy'. The Military Branch deduced that although the Australian Minister for Defence had 'laid emphasis on the need for Australian armed forces to be able to act independently and, insofar as the ability to co-operate with Allies was concerned, seemed to lean towards co-operation with the U.S. rather than with the U.K', the 'decisions actually taken by the Defence Minister - especially the decision to abolish the Australian F.A.A. [Fleet Air Arm] - seem to point the other way, at least so far as the R.A.N. is concerned'. ${ }^{14}$ Despite British hopes, the RN was ultimately outflanked by the USN.

Throughout the 1950s and 1960s, the Americans enacted a number of measures that were intended to stimulate standardisation between the armed forces of Australia and the United States. National Security Council Report 6109 (NSC 6109), issued on 16 January 1961, furthered the notion that:

the United States should continue to urge Australia progressively to standardize its military equipment using United States standards and continue to facilitate, as appropriate, the purchase by Australia of United States equipment for its own forces. $^{15}$

That sentiment built upon the collective defence arrangements: the ANZUS Treaty (1951); the Radford Collins Agreement (1951), which provided for naval cooperation between ANZAM (Australia, New Zealand and Malaya area) forces and Commander in Chief, US Pacific Command; the South East Asia Treaty Organisation (1955) and the Military Standardization Agreement (1960). When the possibility of Australia purchasing the Charles F. Adams class destroyers arose, Avery Peterson, Deputy Assistant Secretary of State for Far

\footnotetext{
${ }^{14}$ The abolition of the Fleet Air Arm was ultimately postponed. TNA, Head of Military Branch II, 'Future of the Royal Australian Navy: Brief for Discussions with Vice Admiral Burrell', 8 January 1960, ADM 1/26681.

15 NARA, Memorandum from FE - Roger Hilsman to David Ball, Administrator, Agency for International Development, '1550 Determination for Financial Assistance to Australia for the Procurement of a Third Charles F. Adams Class Destroyer in the United States’, 18 April 1963, Record Group 59, Box 16.
} 
Eastern Economic Affairs, viewed it as an opportunity to correct an anomaly in standardisation between the armed forces of Australia and the United States:

As I understand it, past progress in achieving a great degree of compatibility between the armed forces of Australia and the United States has been made primarily in the Australian Air Force and Army. Now it appears we have an opportunity to promote this program in the Australian Navy, which traditionally has had greater affinity for the United Kingdom. ${ }^{16}$

Standardisation with the RAN was not merely an ideal eventuality for the Americans. Rather, it was a reality that the Americans worked tirelessly to enact.

When the issue of providing credit to the Australians for the purchase of the American-built guided missile destroyers (DDGs) came under question, W. Averell Harriman, Assistant Secretary of State, contended that:

We wish Australia to augment her armaments and to achieve greater weapons compatibility with the United States...In the final analysis our own self-interest should govern, and I submit that it is without doubt to our interest to add to our strength in Far Eastern waters in a manner that is completely standard with the United States Navy. ${ }^{17}$

The decision to try to enact standardisation with the RAN was not simply a political decision and the USN actively encouraged both their political masters and Australian counterparts to facilitate the process. When Vice Admiral Burrell met with Admiral Arleigh Burke, the Chief of Naval Operations, to discuss the 'possibilities for strengthening the Australian Navy with Untied States Navy vessels and equipment', Admiral Burke made it clear that his position was 'one of wholehearted support for fulfilling any Australian Navy need if at all possible' and that he was "not agreeable to letting red tape and secondary considerations stand in the way of meeting these Australian needs if they can be met from existing United States Navy

\footnotetext{
${ }^{16}$ NARA, Letter from Avery F. Peterson to Mr. Robert M. Knight, Deputy Assistant Secretary of Defense, 15 December 1960, Record Group 59, Box 16.

${ }^{17}$ NARA, Letter from W. Averell Harriman, Assistant Secretary of State, to Paul H. Nitze, Assistant Secretary of Defense, Undated, Record Group 59, Box 16.
} 
stocks of vessels and equipment'. ${ }^{18}$ The Australian willingness to purchase Americandesigned and built equipment and the desire of the USN to enact standardisation with a reliable partner in the Pacific set in train a process, which would ultimately transform the RAN.

\section{Standardisation with the USN: Purchasing the DDGs}

The turn towards standardisation with the USN was both drawn out and multi-faceted. Perhaps no other decision better characterised the shift than the RAN's selection of the American designed and built Charles F. Adams class destroyer as their new type of escort. The decision was reached for pragmatic financial and practical reasons but compatibility with the USN was also at the forefront of Australian thinking. The initial selection process was far from straightforward, although the options were considerably narrowed through consideration of likely coalition partners. Ultimately, the three realistic candidates were the RN's 6,000 ton County class destroyer, the USN's 3,400 ton Brooke class frigate or the another USN ship, the 4,500 ton Charles F. Adams class destroyer. ${ }^{19}$ The selection of the County class would have been a natural progression in view of the fact that the vast majority of the Australian fleet was British-designed, the RAN had predominantly operated under British tactical control during conflict and a large proportion of senior officers had undergone significant RN training. ${ }^{20}$

Nevertheless, forecasts projected that the USN was a more likely and potentially even more reliable coalition partner for the RAN than the RN during any future contingencies. At a

\footnotetext{
${ }^{18}$ NARA, Letter from SPA - James D.Bell to Fe- Mr. Avery F. Peterson, 'Australian Interests in United States Submarines and Guided Weapons Destroyer’, 5 December 1960, Record Group 59, Box 16.

${ }^{19}$ Jones, "Buying the DDGs", 318.

${ }^{20} \mathrm{McNeill}$, 'The Australian Army and the Vietnam War', 49.
} 
meeting at the Pentagon on 6 June 1956, the leader of the McBride Mission, the Minister for

Defence, Sir Philip McBride, offered the following commitment to the Americans:

we must direct our efforts toward closest association with our allies in all contingencies...I would like to stress with the greatest emphasis I can the importance of this decision that we have made; that is, that our forces should be equipped with modern equipment, standard or compatible with that of the U.S. forces because we recognize quite clearly in any of these contingencies that may occur we will obviously be playing our part in close association with your forces in that area. ${ }^{21}$

The perceived likelihood of operating with the USN undoubtedly increased the appeal of the Charles F. Adams class destroyer.

There is no indication that the RAN was prepared to sacrifice quality for compatibility and it is perhaps telling that the USN ship was only selected after a rigorous inspection tour, which included visits to both Britain and the United States. The British pushed their own ship designs vigorously and concluded that Vice Admiral Burrell was 'very much taken with the [HMS] Hampshire', one of the County class guided missile destroyers. ${ }^{22}$ Although Burrell was able to appreciate the qualities of the County class, he did not feel that it could meet the RAN's requirements without modification. The RN duly offered to examine the feasibility of modifying the County class but, in truth, there was some scepticism about the realism of the RAN's ambition. ${ }^{23}$

The armament of the ship was also a concern. The County class design included 4.5inch calibre guns and the Sea Slug surface-to-air missile system, neither of which were favoured by the Australians. ${ }^{24}$ Instead, the RAN indicated that they would prefer the 5"/54 calibre guns and Tartar missile system, which were fitted to the Charles F. Adams class.

\footnotetext{
${ }^{21}$ NARA, 'Minutes of Australian Mission Meeting, 6th June 1957', 20 June 1957, Record Group 59, Box 2.

${ }^{22}$ TNA, Letter from D. Royal, Head of Military Branch II to Commodore J. Plunkett-Cole, Australia House, 14 March 1960, ADM 1/29326.

${ }^{23}$ TNA, 'Meeting Between First Sea Lord and Australian C.N.S.', 13 January 1960, ADM 1/26681.

${ }^{24}$ The RAN were distinctly unimpressed with the Sea Slug following weapon trials conducted at Woomera. Whilst the Sea Slug maintained an advantage over the Tartar in terms of range and velocity, it was assessed that the American system had a better air detection system and was more reliable. Goldrick and Jones, Struggling for a Solution, 14; Burrell, Mermaids do Exist, 254-255; Wallace, thesis, 174-175.
} 
After an investigation into the feasibility of incorporating those weapon systems in the County class design, the RN concluded that 'the design effort required of the Admiralty would have caused an unacceptable delay of two to three years in the development of Royal Navy projects' ${ }^{25}$ Consequently, the Australians decided that the Charles F. Adams class destroyer would be the most effective ship and the most suitable for their needs.

As with any major military acquisition, cost was also an important factor in the Australian selection process. The decision to purchase the American ships was smoothed by monetary considerations after the US agreed to finance the transaction through the Military Assistance Program in May 1961 and the National Advisory Council consented to waive any interest charges. ${ }^{26}$ The Australians made a formal proposal for credit for the outlay of \$US 90 million, which was based on a cost $\$$ US 45 million for each of the two ships that were to be ordered, in view of the fact that the cost was so substantial relative to their defence budget that the payments needed to be spread over an extended period. ${ }^{27}$ As a result, the Australians were only required to make an immediate payment of just \$US 1.5 million, with the remainder being paid over an eight year period. ${ }^{28}$ Subsequently, it was announced on 29 June 1961 that the RAN had selected the Charles F. Adams class ships as its next generation of destroyers.

When the RAN mooted the possibility of purchasing a third Charles F. Adams class destroyer, Robert McNamara, the Secretary of Defense, indicated that the US was willing to provide credit, without interest, as long as 'the Australian payment schedule met the Navy's required progress payments, or if the Australians were ready to pay in equal instalments over a period of seven years', otherwise interest would be charged at a commercial rate of 4.5

\footnotetext{
${ }^{25}$ Jones, "'Buying the DDGs"', 320.

${ }^{26}$ NARA, Letter from W. Averell Harriman, Assistant Secretary of State, to Paul H. Nitze, Assistant Secretary of Defense, Undated, Record Group 59, Box 16.

${ }^{27}$ NARA, Letter from John M. Stevens to Paul H. Nitze, Assistant Secretary of Defense, 9 March 1961, Record Group 59, Box 16.

${ }^{28}$ Jones, "Buying the DDGs", 319-320.
} 
percent on any difference between the Australian payments and the required progress payments to the USN. ${ }^{29}$ On 19 February 1963, Senator John Gorton, the Minister for the Navy, indicated that Australia would agree to the annual repayment plan for the costs of the basic vessel. ${ }^{30}$ Consequently, 'in order to promote foreign policy and national security objectives', the US provided a seven-year credit to the Government of Australia in the amount of $\$ 37,632,000$ to facilitate the purchase of a third DDG under the terms of the Foreign Assistance Act (1961). ${ }^{31}$ A further credit of \$US 7.6 million for armaments, ammunition, and spares was the subject of a separate purchase. ${ }^{32}$

In considering acquisition options for a fourth destroyer, the RAN examined the capabilities of the County class, the RN's Type 52 and the Charles F. Adams class. The submission for Cabinet concluded:

Logistic considerations further emphasise the desirability of the CHARLES F. ADAMS class as the choice for a new comprehensive escort for the RAN. The large number of this class in service with the USN makes it a reasonable expectation that the logistic requirements for the ships in our forward area of interest will be met in the foreseeable future. In the Australia area, the base spares, training equipment and practice and support facilities which are already provided for three D.D.G.'s will provide basically for the fourth. ${ }^{33}$

Financial concerns ultimately militated against the acquisition of a fourth destroyer, with Cabinet rejecting the proposal for a further purchase in 1965. Even so, the reasoning behind the RAN's decision indicated that the move towards American designs was becoming increasingly instinctive.

\footnotetext{
${ }^{29}$ NARA, William P. Bundy, Assistant Secretary of Defense, Memorandum of Record, 'Visit of Australian Navy Minister Gorton to Secretary McNamara', 18 February 1963, Record Group 59, Box 16.

${ }^{30}$ NARA, Letter from Paul H. Nitze, Assistant Secretary of Defense to Honorable W. Averell Harriman, Assistant Secretary of State, 'Your Letter Dated 15 February 1963 Concerning the Sale of a Third Adams Class Destroyer to Australia', 1 March 1963, Record Group 59, Box 16.

${ }^{31}$ NARA, Memorandum from FE - Roger Hilsman to David Ball, Administrator, Agency for International Development, ' 1550 Determination for Financial Assistance to Australia for the Procurement of a Third Charles F. Adams Class Destroyer in the United States', 18 April 1963, Record Group 59, Box 16.

${ }^{32}$ NARA, Memorandum from FE - Roger Hilsman to U - Mr. Ball, 'Sale of Destroyer to Australia', 8 May 1963, Record Group 59, Box 16.

${ }^{33}$ National Archives of Australia, 'Submission No.329 for Cabinet: Acquisition of a Fourth Charles F. Adams Class Destroyer (D.D.G.) for the RAN', 20 July 1965, A5841, 329.
} 
Whilst the Australians were satisfied with their purchases and eagerly awaited their arrival, the US was equally pleased with the transactions. The purchase of the DDGs, as well as other military technology, including the F-111 aircraft, prompted Edward Clark, the American Ambassador to Australia, to declare in 1966 that Australia had 'been most cooperative with us in the field of procurement, against rather strong competition and political pressure from the British'. ${ }^{34}$ In justifying the sale, Roger Hilsman, Assistant Secretary of State for Far Eastern Affairs, stated:

It is understood that the Australian Government's desire to obtain the vessel stems from a well conceived extant program to create a modern missile-age navy tailored to the requirements of Pacific defense and capable of operating in close conjunction with the United States Navy. The ability of the Royal Australian Navy to utilize the vessel effectively and to fulfil the objectives of its modernization is beyond question. ${ }^{35}$

Put simply, the Americans were 'gratified from a military point of view in having more ships of the same general class in being in the world in the hands of allies'. ${ }^{36}$ The acquisition decision was based, in part, on the likelihood of the RAN and USN operating in partnership in the future. That opportunity would arise sooner than either navy may have expected.

\section{Testing the Theory: The RAN at War in Vietnam}

Despite the perceived success of the acquisition, the first real test of the effectiveness of standardisation between the RAN and USN was initiated by Australia's involvement in the Vietnam War. In order to supplement the USN, the RAN made a modest but important

\footnotetext{
${ }^{34}$ NARA, Letter from Edward Clark, American Ambassador, Embassy of the United States, Canberra to Mr. Robert S. Lindquist, Country Director, Australia, New Zealand and South Pacific Islands Affairs, Department of State, 26 September 1966, Record Group 59, Box 9.

${ }^{35}$ NARA, Memorandum from FE - Roger Hilsman to David Ball, Administrator, Agency for International Development, ' 1550 Determination for Financial Assistance to Australia for the Procurement of a Third Charles F. Adams Class Destroyer in the United States', 18 April 1963, Record Group 59, Box 16.

${ }^{36}$ NHHC, Reminiscences of Rear Admiral Ralph Kirk James, U.S. Navy Retired, Annapolis, U.S. Naval Institute, 1973, 379.
} 
commitment of a single destroyer on a rotational basis between March 1967 and September 1971. Although not as diverse as the Second World War, the RAN undertook a wide range of missions during the Vietnam War. RAN ships patrolled off the coast of North Vietnam, took part in interdiction missions, provided naval gunfire support (NGS) in South Vietnam and even contributed to in-country river operations on occasion. RAN destroyers also intermittently formed part of the aircraft carrier screen at Yankee Station. ${ }^{37}$ In total, Australian ships steamed 397,000 miles and fired 102,000 rounds. The contribution of the RAN was numerically minor but in addition to the political value of Australian involvement, the ships were able to make a worthwhile contribution to the naval effort.

In particular, RAN ships achieved distinction through their contribution to the NGS effort. The provision of NGS by the RAN and USN to forces operating ashore was a continuous feature across all four Corps Tactical Zones during the Vietnam War. Vietnam's long coastline, which stretched for approximately 1,200 miles, and the numerous significant strategic areas that were located in coastal enclaves, made naval gunfire an extremely useful commodity. ${ }^{38}$

Naturally, the DDGs were the RAN's first choice when it came to deciding which ships would be deployed to Vietnam. HMAS Hobart and HMAS Perth deployed to Vietnam on three occasions, while HMAS Brisbane undertook two tours. The requirement to maintain continuous deployments of ships to Vietnam exposed the RAN's limited collection of three DDGs. The problem came to the fore when Brisbane was due to be relieved in September 1969. As Perth was scheduled for a refit and Hobart was committed to other duties, the RAN was compelled to deploy a British-designed ship to Vietnam. The deployment of a non-US designed ship to an American operation created serious concerns within Australia, which

\footnotetext{
${ }^{37}$ Paget, 'Old but Gold', 77.

${ }^{38}$ Marolda, By Sea, Air, and Land, 137; NHHC, 'MACV Lessons Learned No.62: Salient Lessons Learned', 11 March 1967, Collection 372, Box 51.
} 
prompted an investigative team to be deployed to Subic Bay. Following exploratory meetings with the USN, the Minister for the Navy, Bert Kelly, received assurances that logistic support for a Daring class destroyer was 'merely a problem to overcome'. ${ }^{39}$ Consequently, HMAS Vendetta was nominated for service in Vietnamese waters and served with the USN between September 1969 and March 1970. The decision also had the added benefit of helping to maintain morale. Senior RAN figures were conscious of an emerging sentiment within the navy that 'only the DDGs were considered as first eleven ships' and deployment of a British type ship was seen as a way to address the problem. ${ }^{40}$

The DDGs were new ships that were fitted with the latest technology but perhaps more importantly, the Charles F. Adams class was in service with the USN and ships of that type were being operated in Vietnam, which made them a natural fit. The ship's two 5-inch automatic rapid fire guns offered sufficient range to make them extremely useful for Sea Dragon operations off the coast of North Vietnam. ${ }^{41}$ In contrast, as a Daring class destroyer, HMAS Vendetta was an older generation of ship and varied significantly from the ships that were being operated by the USN in Vietnam. Nevertheless, the capacity of Vendetta's six 4.5-inch guns to fire up to one hundred rounds per minute in good conditions made her a valuable asset when NGS was required. ${ }^{42}$ In total, during the RAN commitment to Vietnam, the destroyers fired approximately $80,0005 \% / 54$ and $6,8004.5 \%$ rounds at a daily average of 115 rounds per day. ${ }^{43}$ While the impact of the RAN's contribution to the overall war effort was understandably limited, as indeed were naval operations in general when the outcome of the war is considered, the influence of the Vietnam experience on the service was significant.

\footnotetext{
${ }^{39}$ Frame, Pacific Partners, 114-115.

${ }^{40}$ Grey, Up Top, 85.

${ }^{41}$ Operation Sea Dragon was initiated on 25 October 1966 and involved ships engaging a range of targets up and down the North and South Vietnamese coastlines. Targets were varied and included bridges, boat repair facilities and enemy artillery positions.

${ }^{42}$ Perryman and Mitchell, Australia's Navy in Vietnam, 7.

${ }^{43}$ Sea Power Centre-Australia (SPC-A), 'Summary of RAN Naval Gunfire Support Operations: Vietnam, 19671971’, 1974, A703/T111, Misc Docs 3V.
} 
The RAN's involvement in the Vietnam War provided the testing ground for both new procedures and equipment.

Whilst working knowledge of an American ship was an inevitable by-product of the decision to purchase the Charles $F$. Adams class destroyers, the re-equipping process also afforded the Australians an opportunity to acquire an understanding of USN TTPs. Before the ships were in service with the RAN, specialist teams that would form part of the commissioning crews were dispatched to United States, where they underwent extensive training alongside their USN counterparts in order to become accustomed 'with new design characteristics, new conditions of habitability, new weapons systems and, new capabilities' ${ }^{44}$

Even those crew members who did not undergo specialist training were familiarised with the USN's way of conducting business. RAN work-ups were tailored to ensure that Australian DDGs undertook similar shake-downs and trials to those performed by sister ships in service with the USN. Captain Guy Griffiths, Commanding Officer of Hobart during her first tour to Vietnam, explained that:

it was assessed as most important to subject the ship and her company to the full USN schedule for shake-down as fixed by the Fleet Training Group, in order to gain a very close understanding of USN drills, operations and procedures in this US designed destroyer. ${ }^{45}$

The shake-down and work-up periods included dealing with aerial, surface and sub-surface threats. NGS training was a prerequisite and the exercises were conducted with the assistance of United States Army and United States Marine Corps spotters in order to introduce the gun crews to US practices. ${ }^{46}$ The shake-down and work-up programmes also devoted significant time to addressing communications, logistics and maintenance issues.

As a Daring class, Vendetta was subjected to a modified programme, which reflected the difficulties of dispatching a single, non-standardised ship to Vietnam. Vendetta's

\footnotetext{
${ }^{44}$ Griffiths, 'DDGs in Vietnam', 330.

${ }^{45}$ Ibid., 331.

${ }^{46}$ Leach, 'DDGs in Vietnam', 338-339.
} 
programme necessarily included practical training to familiarise the ship's company with the various work-arounds that were required for the vessel's deployment such as the specially installed probe refuelling equipment. ${ }^{47}$ RAN crews became accustomed to the modifications without any significant difficulties during the work-up period. Whilst the scale was obviously not as large as for Vendetta, all RAN crews, even those of the DDGs, had to become accustomed to new equipment for service with the Seventh Fleet. The Australian crews were not the only benefactors of the work-up period, as the Americans were able to use the process to gauge the capability of the Daring class destroyer and assess her likely utility in Vietnam.

It is notable that each RAN commanding officer explicitly recognised the value of working-up with elements of the American military. ${ }^{48}$ Captain Griffiths recorded:

I was also pleased with the sound degree of understanding in the ship of USN procedures which had begun with trials and shakedown. There was resultant potential for a close degree of operational integration to be achieved with the RAN crew in an American-designed DDG. ${ }^{49}$

The work-up process also provided RAN crews with an insight into likely operations in Vietnam. In addition to the traditional workup, as dictated by Australian Fleet General Orders, RAN ships engaged in a pre-deployment exercise in Australia known as CHE SARA. ${ }^{50}$ The involvement of an experienced officer from Sub-Unit One, $1^{\text {st }}$ ANGLICO (Air Naval Gunfire Liaison Company), at the RAN's request, added an air of realism and ensured that Australian procedures were compatible with those used by the Americans. ${ }^{51}$

\footnotetext{
${ }^{47}$ SPC-A, 'Summary of RAN Naval Gunfire Support Operations: Vietnam, 1967-1971', 1974, A703/T111, Misc Docs 3V.

${ }^{48}$ Australian War Memorial (AWM), 'HMAS Perth: Report of Proceedings, February 1966', 24 March 1966, AWM 78, 292/5; Leach, 'DDGs in Vietnam', 338-339; Griffiths, 'DDGs in Vietnam', 332-333; AWM, 'HMAS Brisbane: Report of Proceedings, May 1968', 4 June 1968, AWM 78, 70/1.

${ }^{49}$ Griffiths, 'DDGs in Vietnam', 332-333.

${ }^{50}$ SPC-A, 'Summary of RAN Naval Gunfire Support Operations: Vietnam, 1967-1971', 1974, A703/T111, Misc Docs 3V.

${ }^{51}$ Grey, Up Top, 138.
} 
RAN ships continued their preparations with a short period of type training with the USN at Subic Bay prior to the commencement of operations. ${ }^{52}$ At Subic, RAN crews were subjected to a series of informative lectures and briefings on various topics, including Seventh Fleet organisation, logistic and administrative support and the nature of operations in Vietnam. Under the terms of the 'Logistic and Administrative Supplement to Military Working Agreement' RAN units were afforded access to the 'training facilities, equipment, and aids' that were available to USN ships. ${ }^{53}$ Access to Tabones Range, near Subic Bay, allowed RAN crews to practise the provision of NGS in accordance with USN TTPs and to experiment with extended range procedures, which was a regular requirement in Vietnam. ${ }^{54}$ The physical structure of the ships was merely the platform for co-operation and it proved invaluable for the RAN to work on advancing interoperability with the USN, both before the ships deployed and once they arrived in theatre.

Although standardisation of platforms was achieved through the RAN's acquisition of the Charles F. Adams class ships, a number of work-arounds were still required for integration into the Seventh Fleet and operations in Vietnam. The work-arounds included both the introduction of new equipment and minor modifications to existing equipment. For example, in order to transfer missiles at sea, a modified housefall rig and stops were welded to the guide tracks of Perth to prevent unwanted movement on board the ship. ${ }^{55}$ For the DDGs, few modifications were required and those that were installed were largely insignificant. The same cannot be said for the British-pattern Daring class destroyer, which

\footnotetext{
${ }^{52}$ SPC-A, 'HMAS Hobart - Report No.1', 16 April 1968, A703/T111, Misc Docs 3V; Griffiths, 'DDGs in Vietnam', 332.

${ }^{53}$ NHHC, 'Logistic and Administrative Supplement to Military Working Agreement between Chief of Naval Staff Royal Australian Navy and Commander in Chief U.S. Pacific Fleet', 1 March 1967, Collection 354, Box 531.

${ }^{54}$ AWM, 'HMAS Perth: Report of Proceedings, September 1967', 3 October 1967, AWM 78, 292/5.

${ }^{55}$ NHHC, 'Signal from HMAS Perth to the Flag Officer Commanding, H.M. Australian Fleet: "Tartar Missile System: Commanding Officer's Narrative Report”, Period of Report: 1 January 1968 to 31 March 1968, Collection 372, Box 396.
} 
required further changes. Extensive arrangements, code named 'Plan Familiar', were put into place prior to the departure of the ship, which resulted in major modifications in order to aid interoperability with the Seventh Fleet. ${ }^{56}$

The Americans also had to make preparations to receive Vendetta in theatre. The Australian Commonwealth Naval Board (ACNB) requested that the Commander-in-Chief, Pacific Command (CINCPAC) authorise USN support and logistic arrangements to provide essential facilities for the operation of Vendetta in Vietnam. As a result, the Americans provided storage and disposition on station for Australian 4.5" ammunition, storage space at Subic Bay for RAN stores, maintenance support at Ship Repair Facility (SRF) Subic and the supply of special equipment from the Seventh Fleet pool. ${ }^{57}$ Vendetta was a novelty for SRF staff and the RAN was required to furnish the USN with complete sets of drawings, handbooks, docking plans, spare parts allowance lists and Weapons Maintenance schedules. ${ }^{58}$ In order to accommodate Vendetta's use of atypical ammunition, the Navy Office commissioned the design and production of ammunition pallets to house 4.5 " shells on board US supply ships for the purpose of replenishment at sea.

The concurrent utilisation of the Charles F. Adams class destroyers enabled the two navies to develop common procedures for maintenance and repairs. Based on American experiences of barrel wear in Vietnam, the RAN reconsidered their procedure for re-gunning, which resulted in the acceptance of a common process for both navies. Whilst equipment standardisation in peacetime offers the prospect for interoperability in warfare, it is not a foregone conclusion. It was active cooperation between the RAN and USN in relation to the common equipment, which resulted in such a high standard of interoperability.

\footnotetext{
${ }^{56}$ SPC-A, 'Summary of RAN Naval Gunfire Support Operations: Vietnam, 1967-1971', 1974, A703/T111, Misc Docs 3V.

${ }^{57}$ SPC-A, 'Signal from ACNB to CINCPACFLT: "Deployment of RAN DD for Vietnam Service", 22 April 1969, Record Group 41, Folder 1.

${ }^{58}$ SPC-A, 'Summary of RAN Naval Gunfire Support Operations: Vietnam, 1967-1971', 1974, A703/T111, Misc Docs 3V.
} 


\section{Interchangeability}

In view of the shortage of USN ships available for deployment to Vietnam, the interchangeability provided by RAN DDGs and the modifications undertaken to Vendetta under 'Plan Familiar' allowed Australian ships to help rectify the shortfalls. In particular, the Seventh Fleet often found itself short of 5"/54 ships, which made the RAN DDGs especially valuable and in the absence of other ships of that variety, made ground units dependent on RAN ships on occasion, particularly when they were in need of extended range capability. ${ }^{59}$ According to a Military Assistance Command, Vietnam (MACV) assessment, 'the diversity of ships, guns, and ammunition used in providing NGFS offers considerable flexibility, both to the gunline and ground commanders' ${ }^{60}$ By the end of 1970 , DDGs accounted for $10 \%$ of NGS missions and only $11 \%$ of the rounds expended during those firings. Whilst the number of firings was limited, the ships were essential for extended range shoots when cruisers or battleships were unavailable. Tellingly, DDGs were responsible for $34.2 \%$ of Sea Dragon missions, which often required an extended range capability. ${ }^{61}$ Limitations of particular types of ships in Vietnam meant that the RAN's limited commitment of a single DDG proved to be valuable beyond the Australian's meagre numeric contribution.

The utility of simultaneously maintaining a range of different ship capabilities on station was revealed during both of Brisbane's deployments to Vietnam. Intermittently in 1971, the ship was limited to undertaking missions outside the range of $5 " / 38$ ships due to

\footnotetext{
${ }^{59}$ AWM, 'HMAS Brisbane: Report of Proceedings, August 1971', 31 August 1971, AWM 78, 70/4; AWM, 'HMAS Hobart: Report of Proceedings, June 1967', 10 July 1967, AWM 78, 141/6 Part 3.

${ }^{60}$ NHHC, United States Military Assistance Command Vietnam, 'Vietnam Lessons Learned No.77: Fire Support Coordination in the Republic of Vietnam', 20 May 1970, Collection 372, Box 52.

${ }^{61}$ NHHC, 'Operations Evaluation Group Study 745: Naval Gunfire Support in Southeast Asia', January 1972, 12, Collection 7, Box 66.
} 
difficulties with barrel wear and problems with $5 \% / 54$ ammunition. ${ }^{62}$ In contrast, during an earlier deployment in 1969, when ships equipped with 5\%/38 mounts encountered problems with ammunition, Brisbane was placed on standby to assume responsibility for the lion's share of NGS missions. ${ }^{63}$

At the same time, it should be noted that standardisation was also marked by an inherent difficulty. Operating the same ships and equipment inevitably made RAN units susceptible to the problems that were experienced by their USN counterparts, which had knock-on effects for the provision of NGS in Vietnam. Most notably, batches of defective equipment and malfunctioning communication technology hampered the performance of vessels from both navies. The quality of 5"/54 cartridges was a constant concern throughout the campaign but never more so than when all firings of that particular type of ammunition were suspended in April 1967. As Hobart was the only RAN vessel in theatre, Australian involvement in offensive naval operations was effectively halted, albeit temporarily. Interestingly, it was somewhat fortunate that at the peak of the problems with the $5 " / 54$ ammunition, Vendetta was the RAN ship deployed to Vietnam and was able to maximise the use of her $4.5 "$ ammunition. ${ }^{64}$ The RAN's reliance on the USN for logistic support to the DDGs ensured that the availability and effectiveness of RAN units were occasionally beyond Australian control.

\section{The Gap Between Standardisation and Interoperability: The Operational Challenges of the Vietnam War}

\footnotetext{
62 SPC-A, 'HMAS Brisbane (D41): Vietnam Report 20/71', 30 August 1971, Record Group 41, Folder 4; AWM, 'HMAS Brisbane: Report of Proceedings, August 1971', 31 August 1971, AWM 78, 70/4; AWM, 'HMAS Brisbane: Report of Proceedings, September 1971', 1 October 1971, AWM 78, 70/4.

${ }^{63}$ AWM, 'HMAS Brisbane: Report of Proceedings, July 1969', 1 August 1969, AWM 78, 70/2.

${ }^{64}$ SPC-A, 'Summary of RAN Naval Gunfire Support Operations: Vietnam, 1967-1971', 1974, A703/T111, Misc Docs 3V.
} 
Although the desire to standardise the navies was based on the rational logic of future cooperation, the actual requirements of operating together had been insufficiently considered, which meant a number of challenges had to be addressed during the Vietnam War. An essential element of coalition naval operations, or any military operation for that matter, is the ability of different units to communicate effectively. The incorporation of an RAN ship into the American organisation necessitated immediate and decisive action. Following confirmation that Hobart would be deploying to Vietnam, CINCPAC decreed that:

HMAS HOBART will participate in SEVENTHFLT operations on same basis as US Navy destroyers assigned and will have need to know essentially same information as other destroyer types performing similar functions. It is not desired that operational and administrative type traffic be designated NOFORN simply because HOBART has joined the team. ${ }^{65}$

As was the case for all USN ships, RAN units received track messages from the unit commander. ${ }^{66}$ Access to USN communications was not unfettered and the RAN was only provided access to American communications that were deemed as 'need to know' for operational purposes. In order to facilitate the prompt exchange of information, the classification 'NOFORN EXCEPT AUSTRALIA' was introduced to classify material that was deemed to be releasable to Australia. ${ }^{67}$

Following authorisation by the USN's Chief of Naval Operations, Hobart was authorised to copy two channels of the US Navy Fleet Radioteletype Broadcast in the Western Pacific, which contained most of the communications traffic that was classified as secret and below. ${ }^{68}$ As a result, RAN destroyers were provided with VHF transceivers and

\footnotetext{
${ }^{65}$ NHHC, 'Signal from CINCPACFLT to ALCOMPAC: “Australian Contribution to FWMAF”, 8 March 1967, Collection 354, Box 531.

${ }^{66}$ NHHC, 'Signal from CTG 77.1 to COMSEVENTHFLT: "HMAS HOBART Ops"', 10 April 1967, Collection 354, Box 531.

${ }^{67}$ NHHC, Department of the Navy: U.S. Naval Forces, Vietnam, Memorandum for all Departments, 'Special Handling of Messages Addressed to SEVENTHFLT units', 11 March 1967, Collection 354, Box 531; NHHC, 'Signal from GENTILE AESC to ALMILACT: "Integration of HMAS HOBART into Free World Military Assistance Force", 27 September 1966, Collection 372, Box 382.

${ }^{68}$ NHHC, Department of the Navy: U.S. Naval Forces, Vietnam, Memorandum for all Departments, 'Special Handling of Messages Addressed to SEVENTHFLT units', 11 March 1967, Collection 354, Box 531.
} 
additional temporary communication fits. ${ }^{69}$ The Vietnam War proved that compatible equipment can be redundant if operational security prohibits connectivity. Although the RAN and USN were operating standardised platforms, the communications fit of the ships differed and American assistance was required to overcome the incompatibilities.

Logistic considerations were also a major concern prior to the commitment of RAN destroyers to Vietnam, which necessitated the production of the 'Logistic and Administrative Supplement to Military Working Agreement'. The agreement was signed by Chief of Naval Staff, Royal Australian Navy (CHNAVSTAFFRAN) and Commander-in-Chief, Pacific Fleet (CINCPACFLT) on 1 March 1967. Under the agreement, CINCPACFLT was responsible for logistic support of RAN destroyers placed under American control on the same basis as the equivalent USN forces. The agreement stated:

RAN units so allocated will be fitted, manned, and equipped initially in accordance with applicable policy and directives subject to such modifications as both CHNAVSTAFFRAN and CINCPACFLT subsequently deem necessary to accomplish those missions actually assigned. Such modifications to fitting and equipment, including any resultant equipment additions, will be accomplished from CINCPACFLT resources on either a temporary or permanent basis, as appropriate. ${ }^{70}$

The Australian Government would reimburse the United States Government for the support provided by the USN, as stipulated by a pre-existing reciprocal agreement between the two nations. ${ }^{71}$ The Australians were responsible for the provision of items that were unique to the RAN

For those items that could not be delivered out at sea, the RAN was able to utilise shore-based replenishments but for all other things, the RAN received underway

\footnotetext{
${ }^{69}$ AWM, 'HMAS Brisbane: Report of Proceedings, April 1969', 1 May 1969, AWM 78, 70/2; NHHC, 'Signal from CINCPACFLT to ALCOMPAC: "Australian Contribution to FWMAF", 8 March 1967, Collection 354, Box 531.

${ }^{70}$ NHHC, 'Logistic and Administrative Supplement to Military Working Agreement between Chief of Naval Staff Royal Australian Navy and Commander in Chief U.S. Pacific Fleet', 1 March 1967, Collection 354, Box 531.

${ }^{71}$ Ibid.
} 
replenishment of ammunition, fuel, food and other essential items from Squadron Three of the Service Force, US Pacific Fleet (SERVPAC), the Seventh Fleet's Mobile Logistic Support. The integration of RAN ships into the USN logistic network was a relatively straightforward process. Brisbane's commanding officer, Captain A. Willis, declared: 'few problems have been experienced in switching to the U.S. Navy Supply Systems again. In fact, with U.S. Navy Type Allowance Lists, the ship's Naval Stores sailors feel very much at home in the U.S. Navy Supply environment., ${ }^{72}$

The commanding officers of Australian ships were all quick to commend the scope and efficiency of the logistic support provided by the Seventh Fleet. Captain Ian Burnside, the Commanding Officer of Perth, was full of praise for the American logistic network: 'In our deployment I can only say that the USN logistic effort was indeed superb...If you wanted it and had the budget - you got it! ${ }^{173}$ For the DDGs, the utility of the system undoubtedly resulted from the build-up of essential ammunition and spares for the Charles F. Adams class destroyer. Therefore, when Perth was re-assigned without warning to Northern I Corps on 29 September 1967, the ship was able to rendezvous with USS Castor twenty-four hours early and even managed to acquire the necessary spare parts to repair the AN/SPS52 radar. $^{74}$

Despite broad compatibility with the USN, even the DDGs required minor modifications in order to receive logistic support from the Americans, including magazine whips, davits and ammunitions corrals. However, the announcement in October 1967 that Perth topped the entire Seventh Fleet in 'Order of Excellence at UNREPS [underway replenishments]' demonstrated that the integration of RAN DDGs into the Seventh Fleet logistic network was achieved with relative ease. ${ }^{75}$ Whilst the modifications to the DDGs were an inconvenience, the deployment of the British-designed Vendetta was problematic.

\footnotetext{
72 AWM, 'HMAS Brisbane: Report of Proceedings, April 1969', 1 May 1969, AWM 78, 70/2.

73 Burnside, 'DDGs in Vietnam', 344-345.

${ }^{74}$ AWM, 'HMAS Perth: Report of Proceedings, September 1967', 3 October 1967, AWM 78, 292/5.

75 AWM, 'HMAS Perth: Report of Proceedings, February 1968', 3 March 1968, AWM 78, 292/6.
} 
The services of HMAS Jeparit were required to transport ammunition for Vendetta's 4.5" guns from Australia to Subic Bay. That transportation required advanced preparation, as the ammunition needed to be stored in USN-type pallets to facilitate stowage in American ammunition ships. Modifications were also required to the ship itself, which resulted in modified 'housefall' kingposts being fitted fore and aft to make the vessel compatible with USN logistics ships. In addition, four probe fuelling points were installed to foster rapid fuelling. ${ }^{76}$ The logistic difficulties created by the deployment of Vendetta were challenging but not insurmountable. Innovative work-arounds and the can-do attitude of both navies smoothed the integration of a non-US designed ship into the Seventh Fleet. The transition was far from seamless but it was successful.

Integration with the Seventh Fleet also provided RAN ships with access to USN SRFs. The completion of mid-deployment upkeep processes for RAN ships was conducted at USN SRF due to their 'ability to handle successfully a large work list in a relatively short time'. ${ }^{77}$ The process for the RAN's Charles F. Adams class destroyers was seamless because the SRF had a working knowledge of the ship. Vendetta proved to be more of a challenge but the necessary support was provided by the facilities. On countless occasions, the repair facilities responded rapidly to immediate maintenance requests by RAN destroyers, which ultimately minimised the length of time that ships were required to be away from the gunline. ${ }^{78}$ Assistance from the Mobile Technical Unit (MOTU), a subsidiary of SRF Subic, provided prompt and effective technical support, which enabled RAN units to rectify defects without leaving station. Similarly, USN accident investigation teams drew on their

\footnotetext{
${ }^{76}$ Fairfax, Royal Australian Navy in Vietnam, 30.

77 AWM, 'HMAS Brisbane: Report of Proceedings, August 1971', 31 August 1971, AWM 78, 70/4; AWM, 'HMAS Hobart: Report of Proceedings, July 1970', 4 August 1970, AWM 78, 141/8; AWM, 'HMAS Brisbane: Report of Proceedings, May 1971', 31 May 1971, AWM 78, 70/4.

78 AWM, 'HMAS Perth: Report of Proceedings, October 1967', 3 November 1967, AWM 78, 292/5; AWM, 'HMAS Hobart: Report of Proceedings, June 1970', 2 July 1970, AWM 78 141/8; AWM, 'HMAS Perth: Report of Proceedings, October 1970', 1 November 1970, AWM 78, 292/7.
} 
knowledge and experience of American DDGs in the Seventh Fleet to provide advice and assistance to RAN ships. ${ }^{79}$ In the case of the DDGs, it was fortunate that faulty or damaged equipment could be replaced through cannibalising the required part from a USN ship that was not required for immediate action.

Integration into the Seventh Fleet also afforded RAN crews direct contact with a series of technical representatives from many of the companies that manufactured the equipment onboard the DDGs. Guidance was regularly sought from representatives of the manufacturers when faults recurred or proved to be beyond the capability of the USN and RAN crews. In operating equipment that was standardised with the USN, the RAN benefitted from advice about a diverse range of equipment, including communication, electric and weapons technology, which helped to uphold the RAN's reputation for keeping ships in an operational state. ${ }^{80}$

The USN logistic system was impressive but far from flawless. After experiencing problems with the ship's 5"/54 gun, Captain Peter Doyle, Commanding Officer of Perth during her first deployment, complained that 'diagnosis of the defects is usually rapid, but gaining access to the defective items is often a very lengthy process ${ }^{81}$ On a few occasions, RAN ships were required to wait extended periods, which could stretch to months, before they received the requested spares. ${ }^{82}$ It was also true that the Australian logistic system was plagued by a combination of shortages and delays. Captain Burnside recalled:

\footnotetext{
79 AWM, 'HMAS Brisbane: Report of Proceedings, July 1969', 1 August 1969, AWM 78, 70/2.

${ }^{80}$ AWM, 'HMAS Brisbane: Report of Proceedings, May 1971', 31 May 1971, AWM 78, 70/4; AWM, 'HMAS Perth: Report of Proceedings, September 1967', 3 October 1967, AWM 78, 292/5; AWM, 'HMAS Perth: Report of Proceedings, November 1967', 8 December 1967, AWM 78, 292/5; AWM, 'HMAS Perth: Report of Proceedings, October 1970', 1 November 1970, AWM 78, 292/7.

${ }^{81}$ AWM, 'HMAS Perth: Report of Proceedings, October 1967', 3 November 1967, AWM 78, 292/5.

82 AWM, 'HMAS Brisbane: Report of Proceedings, May 1969', 1 June 1969, AWM 78, 70/2; AWM, 'HMAS Brisbane: Report of Proceedings, July 1969', 1 August, 1969, AWM 78, 70/2; AWM, 'HMAS Hobart: Report of Proceedings, May 1970', 4 June 1970, AWM 78, 141/8; AWM, 'HMAS Hobart: Report of Proceedings, June 1970', 2 July 1970, AWM 78, 141/8.
} 
With regard to items not on the USN inventory, or which were outside normal USN coverage, we had to rely on Australian supplies. Here we did have problems, particularly when they had to come through Manila or Saigon. In the case of Manila we did not always have good support from the Embassy staff and, with Saigon, the marathon of their customs procedures was often impossible to master. $^{83}$

The Australians received commendable logistic support from the USN in the main, but that dependency created an over-reliance on American support. Australian complacency ultimately resulted in an inability to bridge the gap between the requirements of RAN ships and the capacity of the Americans to provide the requisite support. It was fortunate that, on the whole, USN logistic support was offered without reservation and was generally sufficient to allow the RAN to operate effectively.

Tellingly, the RAN also enacted significant and symbolic changes to its structure, which, in part, reflected the influence of working alongside the Seventh Fleet. On 10 May 1968, the ACNB discontinued the use of Royal Navy squadron numbers and adopted a similar system to their American counterparts. Consequently, the RAN's three DDGs formed the $1^{\text {st }}$ Australian Destroyer Squadron and the three Daring class destroyers comprised the $2^{\text {nd }}$ Australian Destroyer Squadron. The move was accompanied by the introduction of the USN system of hull numbering and the policy of labelling ships by their type and number. ${ }^{84}$ Peter Jones has cautioned that 'the RAN did not adopt USN practices wholesale but rather modified those appropriate to suit the RAN's British derived organisation'. ${ }^{85}$ Far from becoming an appendage of the USN, the changes merely represented a reduction of the British influence on the organisation of the RAN. Perhaps the most symbolic move was the RAN's introduction of the Australian White Ensign in place of the British White Ensign. The structural changes that were enacted by the ACNB went some way to smoothing the

\footnotetext{
${ }^{83}$ Burnside, 'DDGs in Vietnam', 345.

${ }^{84}$ Frame, Pacific Partners, 116-117.

${ }^{85}$ Jones, "'Buying the DDGs", 325.
} 
integration of RAN units into the Seventh Fleet during the Vietnam conflict and also helped to facilitate later naval cooperation between the two nations.

\section{The Lessons of the RAN's Experience}

Although the two obvious markers for the RAN's transition to standardisation with the USN were the decision to purchase the DDGs and their commitment to Vietnam, the intervening period was at least as important. Interoperability at the operational and tactical level does not occur through a process of osmosis simply as a result of purchasing the same platform. Indeed, the extensive effort exerted by both the RAN and USN to achieve compatibility in all areas, from logistics to training prior to the Australian naval commitment to Vietnam, was essential. Even then, specific operational requirements for action alongside the USN during the Vietnam War necessitated the addition of some new equipment and the modification of existing equipment and procedures. In the case of the DDGs, interoperability was achieved with minimal fuss. HMAS Vendetta posed additional problems but endeavour and goodwill by both parties facilitated efficient cooperation during the Vietnam War. Although it is impossible to say with any certainty, it would appear that if the RAN had deployed more than one Daring class destroyer at any given time or deployed multiple Daring's consecutively, then the logistics problems would have been more cumbersome and perhaps even prohibitive. In actuality, the deployment of a single Daring ensured that the allowances made by the Seventh Fleet and the efforts of American personnel to obtain a detailed working knowledge of equipment specific to the Australians allowed impromptu work-arounds to prove to be sufficient to maintain a reasonable level of interoperability.

It should be noted that the RAN's acquisition of the DDGs was not without drawbacks. Jones has surmised that the purchase of the DDGs led to the cessation of 
destroyer construction in Australia, expanded the range of foreign weapon systems in use with the RAN and necessitated the creation of an additional logistic support system that inevitably increased operating costs. ${ }^{86}$ The decision to purchase American-designed DDGs created a further short-term problem, which was also experienced by other navies that underwent a similar change in their acquisition policy. In reference to the development of the Indian Navy, G.M. Hiranandani, has declared that although 'the transition from British to Russian acquisitions did manage to succeed,' it did so 'slowly and tortuously to begin with'. ${ }^{87}$ The RAN's experience mirrored that of the Indians in terms of temporarily creating a two-tier navy. ${ }^{88}$ Jones has outlined:

On one side were the DDGs known as the "tupperware ships" with their crews conversant only in USN procedures but also the considerable jargon needed to crew a US-built ship. On the other side was the rest of the Fleet or the "steel ships". It would be wrong to overemphasise this split, but it was evident. ${ }^{89}$

Although these difficulties do not detract from the success of integrating with the USN during the Vietnam War, they do clearly indicate that significant divergences in acquisition policy predictably create teething problems.

While smaller navies will inevitably strive for independence, there are also widespread benefits to emulating the model of effective larger navies. Tom Frame has contended:

Although the RAN had been created by royal decree in 1911, its customs, traditions and ethos were those of the parent navy from which it had been grafted. In the RAN's formative years, replicating the most powerful navy in the world made good sense. In British eyes, Australian success would be determined by the faithfulness of the copy. ${ }^{90}$

\footnotetext{
${ }^{86}$ Ibid., 326.

${ }^{87}$ Hiranandani, Transition to Triumph, 246.

${ }^{88}$ It should be noted that the experiences were far from identical. For example, the practical difficulties experienced by the Indians such as acute logistic problems were not replicated in Australia.

${ }^{89}$ Peter Jones, "“Buying the DDGs", 326.

${ }^{90}$ Frame, Where Fate Calls, 1.
} 
In addition to the RAN, the development of other navies in the post-Second World War period has demonstrated that compatibility and interoperability with likely coalition partners are often goals that growing navies strive for during their development.

For junior partners, as evidenced by the RAN's involvement in the Vietnam War, interoperability takes on an increasing importance when only limited contributions to multinational operational areas can be made in order to ensure that the commitments are more beneficial than they are a hindrance. Financial considerations, among a number of other practical difficulties, will often prevent smaller navies from standardising platforms with larger navies, particularly across their entire fleets. The RAN's experience in Vietnam proved that ship-designs are merely enablers rather than creators of interoperability. Just as important, if not more so, is the facilitation of compatibility in culture, mindset, training, and ideally TTPs. The deployment of the British-designed HMAS Vendetta to Vietnam demonstrated that the incorporation of a non-standardised vessel into another nation's fleet will inevitably create a range of difficulties, but they can be overcome through a shared understanding.

There can be no doubt that the purchase of the Charles F. Adams class destroyers was a watershed moment for the RAN. Although the RN and USN had actively tried to promote standardisation with the RAN, the purchase of American designed and built ships delineated between a navy moulded on the British model and an increasingly independent service aimed at compatibility with the US. Indeed, while the RAN actively sought greater independence, the Australians were cognisant that future operations, both within their own region and beyond, were likely to be undertaken in partnership with the USN. Arguably, the Australians were vindicated by the fact the DDGs saw service with the USN in Vietnam and HMAS Brisbane went on to serve alongside the USN during the Gulf War. 


\section{References}

\section{Books and Book Chapters}

Burnside, I., 'DDGs in Vietnam: HMAS Perth, 26 September 1970 to 30 March 1971', in T.R. Frame, J.V.P. Goldrick and P.D. Jones (eds.), Reflections on the RAN (Kenthurst, 1991), 343-348

Burrell, H., Mermaids do Exist: The Autobiography of Vice-Admiral Sir Henry Burrell (Melbourne, 1986)

Cooper, A., 'The Effect of World War II on RAN-RN Relations', in D. Stevens (ed.), The Royal Australian Navy in World War II (Sydney, 1996), 44-52

Fairfax, D., Royal Australian Navy in Vietnam (Canberra, 1980)

Frame, T., Pacific Partners: A History of Australian-American Naval Relations (Sydney, 1992)

Frame, T., Where Fate Calls: The HMAS Voyager Tragedy (Sydney, 1992)

Goldrick, J., 'Australian Naval Policy: 1939-45', in D. Stevens (ed.), The Royal Australian Navy in World War II (Sydney, 1996), 1-17

Goldrick, J. and Jones, P., Struggling for a Solution: The RAN and the Acquisition of a Surface to Air Missile Capability (Canberra, 2000)

Grey, J., Up Top: The Royal Australian Navy and Southeast Asia Conflicts: 1955-1972 (Sydney, 1998)

Griffiths, G., 'DDGs in Vietnam: HMAS Hobart, 7 March to 27 September 1967', in T.R. Frame, J.V.P. Goldrick and P.D. Jones (eds.), Reflections on the RAN (Kenthurst, 1991), 330337

Grove, E., 'British and Australian Naval Policy in the Korean War Era', in T.R. Frame, J.V.P. Goldrick and P.D. Jones (eds.), Reflections on the RAN (Kenthurst, 1991), 245-274

Hiranandani, G.M., Transition to Triumph: History of the Indian Navy, 1965-1975 (New Dehli, 2000)

Hyslop, R., Australian Naval Administration, 1900-1939 (Melbourne, 1973)

Jones, P., "'Buying the DDGs", ANZUS Naval Relations, 1951-85', in T.R. Frame, J.V.P. Goldrick and P.D. Jones (eds.), Reflections on the RAN (Kenthurst, 1991), 316-329 
Leach, D., 'DDGs in Vietnam: HMAS Perth, 19 September 1968 to 19 April 1969', in T.R. Frame, J.V.P. Goldrick and P.D. Jones (eds.), Reflections on the RAN (Kenthurst, 1991), 338342

McNeill, I., 'The Australian Army and the Vietnam War', in J. Doyle, J. Grey and P. Pierce (eds.), Australia's Vietnam War (College Station, 2002), 16-54

Marolda, E.J., By Sea, Air, and Land: An Illustrated History of the U.S. Navy and the War in Southeast Asia (Washington, 1994)

Perryman, J., and Mitchell, B., Australia's Navy in Vietnam: Royal Australian Navy in Vietnam (Silverwater, 2007)

\section{Articles}

Paget, S., 'Old but Gold: The Continued Relevance of Naval Gunfire Support for the Royal Australian Navy', Security Challenges, 10:3 (2014), 73-94

\section{Theses}

Wallace, R.N.W., 'The Australian Purchase of Three United States Guided Missile Destroyers: A Study of the Defense Aspect of Australian-American Relations', unpublished $\mathrm{PhD}$ thesis (Tufts University, 1980) 